Marta Karcz (D) marta.m.karcz@gmail.com (University of Cagliari, Italy)

\title{
The Ripeness of Poetry: Innovation in the Concept of kāvyapāka as Introduced by Bhoja
}

SUMMARY: The paper examines the contribution of Bhoja, an $11^{\text {th }}$-century theoretician of Sanskrit literature, to the theory of kāvyapa $k a$ - the maturity or ripeness of poetry. The concept relies on comparison between a poem and a fruit as they likewise must come to fruition to reach perfection-the state when they are most pleasing to their recipients. The theory is mentioned in numerous important Sanskrit works on poetics. However, different theoreticians perceive the state of perfection in poetry somewhat differently. Bhoja provides yet one more view on this matter. Although he relies on his predecessors, and in some points agrees with them, he also offers fresh perspectives on the subject. The paper focuses on the analyses of relevant passages from Bhoja's works, Sarasvatīkaṇthābharaṇa and Śringāraprakāśa, concerning the subject of $k \bar{a} v y a p \bar{a} k a$, and compares them with the views of other theoreticians as summarized in the first part of the study.

KEYWORDS: kāvyapāka, pāka, prauḍhi, Bhoja, Sarasvatīkaṇthābharaṇa, Śrngāraprakāśa, poetics

What does 'perfection' mean in the context of poetry? What makes a poem perfect and ready to be displayed to the public? The opinion that the ultimate, perfect piece of poetry does not exist would probably prevail today and so would the view that it is up to the reader 
to interpret literary work and judge its merits according to his or her own preferences. However, the theoreticians of Sanskrit poetics undertook the arduous and, in their view, necessary task of defining perfection in poetry and to that end developed the theory of kāvyapāka. One of those who contributed the most to this concept was the $11^{\text {th }}$-century King Bhoja of the Paramāra dynasty.

The word $p \bar{a} k a$ comes from the verbal root pac which means 'to cook', 'to ripen', 'to mature', 'to bring to perfection or completion'. Therefore, the basic meaning of pāka as a noun is 'cooking', ' 'cooked food', 'ripeness (as in a fruit)' or 'maturity'. However, its secondary meaning is 'excellence', 'perfection', 'full development'. Theoreticians of Sanskrit literature used the term kāvyapāka to describe the state where a poem has attained its final form, was ready and finished, hence the poet could stop working on it. Although the word $p \bar{a} k a$ was used in the context of poetry to denote specific literary quality, it still maintained its association with its primary meanings as the degree of maturity of a poem was compared to the measure of ripeness of different kinds of fruits. Over the centuries, theoreticians of Sanskrit literature expressed different views as to what brings about the maturity in a poem. One of the first authors to use the term kāvyapāka and provide its definition was Vāmana (c. $8^{\text {th }}-9^{\text {th }}$ century); however, already before him Bhāmaha (c. $7^{\text {th }}$ century) compared badly composed poetry to an unripe wood apple. ${ }^{2}$ Later on, the discussion on kāvyapāka could

$1 \quad P \bar{a} k a$ is also a branch of śāstra. Pākaśāstra or 'science of cooking' is the knowledge of Indian ayurvedic cuisine. According to Ayurveda, food was one of tristambha - three pillars of human life and therefore there were numerous treatises devoted to culinary art, for example Pākadarpaña of Nala or Bhojanakutūhala of Raghunātha.

2 "That Kāvya which is unpleasing and difficult to analyse is ugly though it may possess Rasa. The composition of some people is like the unripe wood apple". (Kāvyālañkāra 5.62: ahṛdyam asunirbhedam rasavattve 'py apeśalam | kāvyam kapittham āmam yat keșāmcit tādrśs Wood apple is a fruit of limonia acidissima, commonly known also as elephant-apple. 
be found in all major works on poetics, although it was never considered an essential critical device (Battistini 2016: 145).

One of the most important views which gave a new perspective to the idea of poetic maturity was presented by Bhoja. However, in order to evaluate his input into the theory of kâvyapāka, one needs to take a closer look at the opinions of his predecessors since Bhoja refers to them and their ideas while formulating his own judgment.

The first, essential view relating to $p \bar{a} k a$ was provided by Vāmana in his work Kävyālaṇkārasütravrtti. Vāmana considered the concept of pāka to be connected with vaidarbhi poetic diction or rìt $i$ and an element engendering admiration of the connoisseurs. ${ }^{3}$ Thus, $p \bar{a} k a$ was considered crucial to poetry and a factor that made a poem good. According to Vāmana, there were two kinds of kāvyapāka: śabdapāka - 'perfection of words' - and arthapāka - 'perfection of meaning'. He focused on the śabdapāka, about which he said:

\section{ādhānoddharane tāvad yāvad dolāyate manah |}

padasya sthāpite sthairye hanta siddhā sarasvatī ||

Kāvyālaṃkārasūtravrtti 1.3.15, vritti

As long as the mind is hesitating, there is insertion and removing of words.

But once their firmness is accomplished, oh, the poetry is perfect $!^{4}$

Thus, according to Vāmana, a poem is ripe when not a single word needs to be replaced by its synonym. During the creative process, a poet tries to use different words and arrange them in different ways in order to find the best ones for the particular poem. The śabdapāka

3 vacasi yam adhiśayyā syandate vacakaśrīr. vitatham avitathatvam yatra vastuprayāti | udayati hi sa tādṛk vāpi vaidarbhirītau sahṛdayahṛdayānām rañjakaḥ ko 'pi pākah || (Kāvyālaṃkārasūtravrtti 1.2.21 vṛtti)

4 All the translations in the article are mine unless otherwise stated. 
is attained when every word fits in perfectly and the poet is sure that he neither wants to nor needs to change anything. Therefore, it can be said that for Vāmana, śabdapāka denotes the dexterity and precision in combining words in order not only to obtain a result melodious and pleasant to the ears, but also to achieve the artistic aim envisaged by the poet. Hence, śabdapāka in Vāmana's view is very close to another term from the theory of Sanskrit literature-śayya . The term śayyā literally means 'bed', 'couch', 'lying', 'sleeping'. In the Sanskrit theory of literature, it is used to express relation between words in a literary composition, relation allowing the words to lie together in such comfort as a body in bed. Therefore, it is not possible to remove or substitute any of the words as this would destroy their perfect agreement. One could say that certain words are somehow predestined for expressing the particular intention of the poet. Śayyā can be thus understood as the verbal perfection of a work, and, therefore, is very closely related to the theory of kāvyapāka (Lipowska 2016: 352).

In another passage (Kāvyālaṃkārasūtravrtti 3.2.15), Vāmana distinguishes different levels of kāvyapāka. The first one is characterized by the full manifestation of gunas (gunasphutatvasākalyam) and Vāmana compares it to the full ripeness of a mango. A literary work which is based on well-formed verbs and nouns and is qualified by a not easily intelligible subject is the second level of kāvyapāka because it possesses only some of the gunas. This type of work may be described as ripe as an aubergine and is not appreciated by the connoisseurs; however, it is still poetry. Vāmana then points out works that do not possess any gunas. He does not consider them poetry and compares them to an unripe wood apple.

The next theoretician of Sanskrit literature who offered important input to the theory of $k \bar{a} v y a p \bar{a} k a$ was Mangala $\left(10^{\text {th }}\right.$ century $){ }^{5}$ Mangala called his concept parināma, which, similarly to $p \bar{a} k a$, means

5 The work of Mangala has not been preserved as a whole, however, fragments of the text were quoted by Rājaśekhara in his Kāvyamīmāmsāa. See also Krishnamoorthy 1971. 
'ripeness', 'maturity', 'result'. According to him, a poet could master the skill of composing perfect poems through writing exercises and practice. Mangala described this skill as proficiency in using nouns and verbs. He identified kāvyapāka with sauśabdya-the right formation of grammatical forms. Therefore, for Mangala, kāvyapāka was connected more to the grammatical knowledge and constructing correct sentences than to an artistic expression (Lipowska 2016: 353).

Another extensive contribution to the theory of kāvyapāka was made by Rājaśekhara ( $10^{\text {th }}$ century) and his learned wife, Avantisundarī. Their position was expounded in the fifth chapter of Kāvyamimāms $\bar{a}$. Disagreeing with the opinions of Vāmana and Mañgala, Avantisundarī called the inability to substitute words by their synonyms simply a lack of creativity and a weakness on the part of the poets.

Rājaśekhara shared Avantisundarî's opinion that the perfection of poetry can be obtained while using different words. In his view, the essence of the concept of $p \bar{a} k a$ lies in the verbal scope and may be perceived as the power of speech. Therefore, according to Rājaśekhara, poetical perfection is much more than grammatical correctness. It depends also on sounds and combinations of words, their relationship to the topic, and the ability to induce particular rasa. Rājaśekhara, similarly to Mangala, believed that writing perfect poems requires practice. He considered $p \bar{a} k a$ as defining not only the perfection of a literary work but also the maturity of the poet himself - only a proficient poet is capable of writing a perfect poem.

In his further divagations on literary perfection, Rājaśekhara turns to the basic meaning of the term $p \bar{a} k a$. He provides classification of nine kinds of poetic perfection and compares them to the ripeness of different fruits. He indicates three kinds which are truly good (grape, mango and coconut), three which need further work (jujube, tamarind, cucumber) and three which are not acceptable (neem, eggplant, betel nut). He refers to taste sensations associated with consuming the particular fruit and compares them to the location of rasa in literary works. Rājaśekhara remarks that there are many more kinds of $p \bar{a} k a$; however, he selects nine exemplary ones for 
the sake of instructing young poets who want to engage in the exercise and refine their writing skills.

Bhoja refers to $p \bar{a} k a$ in two of his treatises devoted to the theory of Sanskrit literature-Sarasvatīkaṇthābharaña and Śrngāraprakāśa; however, it is the first one, where he gives more space to the subject, that is of greater importance. Therefore, its passages shall be analysed first.

In the Sarasvatīkanthäbharana Bhoja focuses on the concept of $p \bar{a} k a$ in the section called śabdaguna - 'the quality of expression'. However, instead of $p \bar{a} k a$, Bhoja uses the term praudhi. The meaning of praudhi is very similar to that of $p \bar{a} k a$ - maturity, perfection, growth, full development, boldness, exertion, but it lacks the previous culinary connotations. The noun praudhi comes from the verb vah with a prefix pra, which means 'to carry forward', 'to show'. However, this does not mean that Bhoja totally abandons all reference to the ripeness of fruits. Besides, he is not the first theoretician to use the term praudhi in the context of Sanskrit theory of literature. The term occurs earlier in the prologue to Rāmābhyudaya, a play written by king Yaśovarman of Kannauj ( $8^{\text {th }}$ century). A verse in Yaśovarman's work mentions praudhi of śabda and artha, twin concepts related to poetics, and the verse is subsequently quoted both by Bhoja in the ninth chapter of Śrngāraprakāśa and Ānandavardhana in his Dhvanyāloka. Similar term, praudhatvam, can be found in the prologue of Mālatīmädhava by Bhavabhūti ( $8^{\text {th }}$ century). As V. Raghavan observes, "This seems to have developed into the praudhi forming the arthaguna ojas in Vāmana, III.2.2" (Raghavan 1973: 225-226). Vāmana defines one of the arthagunas - namely ojas - as arthasya praudhir, "the maturity of meaning" (Kāvyālamkārasūtravṛtti 3.2.2). Thus for Vāmana praudhi is equated to the ability to write with the intended results in mind. It is also the power to express a vast range of meanings in few words as well as to describe a small thing in an intriguing and elaborate way. The main difference between Vāmana and his predecessors in defining praudhi is that Vāmana classifies it only as an arthaguṇa, while Yaśovarman and Bhavabhūti ascribe it to two categories: śabda 
and artha (Raghavan 1978: 255-256). However, the first theoretician of Sanskrit literature to list praudhi as an independent guna is Bhoja.

In the Sarasvatīkanthābharana 1.77 king Bhoja defines the literary perfection, praudhi, in this manner: "The full development of an expression is known by the name "praudhi'" (ukteh praudhah paripākaḥ procyate prauḍisamjjñayā | Sarasvatīkaṇthābharaṇa 1.77). He described prauḍi as praudha parīpāka - "full development", "full ripeness" of an expression. It seems that he wants to emphasize that literary perfection is the quality of the final shape of the work. This definition is expanded in the commentary written by Ratneśvara (c. $14^{\text {th }}$ century): "This perfection (praudhi) is the ripeness (pāka) of poetic speech. Ripeness is the impossibility of replacing words with their synonyms" (ukter vākyasyāyam pākaḥ sā prauḍhịh| śabdānām paryāyaparivartāsahatvam pākah | Sarasvatīkaṇthābharaṇa, commentary to 1.77). To support his statement, the commentator then quotes a verse by Vāmana, Kāvyālaṃkārasūtravrtti 1.3.15. It can be seen that, according to Ratneśvara, Bhoja mostly agrees with his predecessor on the meaning of $k \bar{a} v y a p \bar{a} k a$ while rejecting the views of Avantisundarī and her husband, who consider the inability of substituting words by their synonyms as a weakness of a poet.

After the definition of $p \bar{a} k a$, Bhoja provides an example - a verse, which according to Jalhana ${ }^{6}$ should be attributed to Cittapa. ${ }^{7}$ It is used to indicate the classification of $p \bar{a} k a$ s and how to determine their kinds:

abhyuddhṛtā vasumatī dalitạ̣ ripūrạ kșiptakramam kavalitā balirājalakșmīh

atraikajanmani kṛtam yad anena yūnā janmatraye tad akarot puruṣạ̣ purānah \|

6 Minister of the Yāḍava King, Kṛ̦ṇa, who in 1257 compiled an anthology, Sūktimuktāvalī. The compilation is particularly important as it contains Rājaśekhara's verses praising great Sanskrit poets (Krishnamachiariar 1974: 385-386).

Poet who flourished in the first half of the $11^{\text {th }}$ century. He was probably a court poet of King Bhoja. His stanzas are frequently quoted in the Sarasvatikanthābharana. (Sircar 1953: 125-126). 
atra prakṛtisthakomalakațorebhyo nāgaropanāgaragrāmyebhyo vā padebhyo 'bhyuddhṛtādīnām grāmyādīnām ubhayeșām vā padānām āvāpodvāpābhyām sanniveśacārutvena yo 'yam ābhyāsiko nālikerapāko mrdvīkāpāka ityādir vākyaparipākah sā prauḍhir ity ucyate | tathā caitad vākyam nālikerapāka ity ucyate | evam sahakāramrị̂̄̄kāpāke apy udāharan̄ìye iti || Sarasvatīkanțāohharana 1.77

The Earth rendered prosperous, the enemy's chest torn asunder, by stomping step the fortune of tributary kings devoured.

What was accomplished by this young man in one lifetime, was done by Viṣnu in three lives. ${ }^{8}$

Here the expression's full ripeness, that is the ripeness of coconut, ripeness of grapes, etc. is called praudhi, and it results from practice in [supplying] charm to the composition by adding and removing words of both kinds like grāmya etc., like abhyuddhrta etc.; or by normal, tender and harsh or sophisticated, common and rustic words. ${ }^{9}$ And therefore, this sentence is called ripe as coconut. The ripeness of mango and grape shall be illustrated in the same way.

Like his predecessor Rājaśekhara, Bhoja uses different kinds of fruits to explain differences between different types of praudhi. The ripeness of grape, mango, and coconut represent three kinds of $p \bar{a} k a$ compositions, which according to Rājaśekhara, as being artistically mature, testify to the artistic fineness of the text - no further work on them is required. According to Bhoja, they are the only pure

8 In this stanza the poet compares deeds of a young hero (probably his royal patron) to the deeds of three avatāras of Viṣnu (Varāha, Narasiṃha and Vāmana) by employing śleșas (abhyuddhṛtā can be translated also as 'lifted up' and balirājalakșmīh as 'the fortune of King Bali').

9 Terms 'normal', 'harsh' and 'tender' refer to sound aspect of words while 'sophisticated', 'common' and 'rustic' refer to their semantic aspect. 
kinds of poetical perfection; however, he admits that there are more types which originate by mixing them. At the end of his commentary, Ratneśvara remarks that these new kinds of $p \bar{a} k a$ configurations belong to the category of arthapākas and therefore they are discussed in the fifth chapter of Sarasvatīkanthābharana. Those mentioned here are discussed in the second chapter along with śabdagunas; therefore, it may be assumed that they are śabdapākas. Although Bhoja compares the three categories of $p \bar{a} k a$ or praudhi to the same kinds of fruits as Rājaśekhara, he perceives them in a different way. His thoughts on the subject are explained by Ratneśvara in the commentary:

prauḍha iti | upakramopasaṃhārayor nirvyūẹhah sa cāyam nā likerasahakāramṛ̂īkopalakșaṇais trividho gīyate | tad yathā nālikeraphalam pakvam tvaci kațhinam śirāsvavivrtakomalaprāyam kapālikāyām kațhinataram tathā kaścit saṃdarbho mukhe kaṭinas tadanantaram mrịduprāyas tatah kaținataro nālikerapāka ity ucyate | tathā hi-prakrtodāharane prathamapāde 'bhyuddhṛteti varnacatuștayam ārambhe kaținam 'vasumatī dali' iti varṇașațam komalam 'tam ripūraḥ' ityanusvārarephadīrghair akșaracatușțayam kaținataram | atrāpi tam iti mṛduprāyaniveśena komalakapāl ikāmukhabhāgasārūpyam drạ̣hayatīty asmadārādhyāḥ | evam dvitīyādipādatraye catuṣkașațkacatușkair nālikeraphalasāmyam unneyam | katham punar evamvidhah pākah sambhavatīty ata āhaatreti $\mid$ abhyāsena nirvrtta ābhyāsikah | kāvyam kartum vicārayitum ca ye jānanti tadupadeśena karaṇe yojane ca paunahpunyena pravrttir abhyāsah | [Mammața, Kāvyaprakāśa 1.3 vrtti] asāv api katham pākaviśeșo bhavatīty ata āha-sanniveśacārutveneti $\mid$ (...) bhavati hi sahṛdayānām evam anyat padam nāstīti vyavahārah | so 'yam racanāsiddhiviśeșah katham anyathā tajjātīyam eva padam anyatra saṃdarbhe niveśitam na tathā svadate | ata evāsau vākyaguṇah | käthinyam ca samyogair dīrghair vā svarair bhavati $\mid$ yathätraivodāharaṇe ripūra ityādau | suptinivyutpattilakṣaṇas tu vārtākapākah kaiścid uktah, sa tu suśabdatālakșaṇaguṇa eva | evam iti | yathā drākșāphalam tvaca ārabhya komalam antarā dvitricaturāsthisampāditam kiṃcit kāthinyam evam kaścit samdarbham upakramopasamhārayoh komala eva madhye kațina 
eva | samyogadīrghasvaramātrakṛtamanākkathorabhāvo mrdvīkāpāka ity ucyate | (...) ata eva kavikalpalatākārāadibhir ukto nīlakapitthapākaścaturtho nāsti | yadvac ca parinatam sahakāraphalam ārambhād eva komalam asthani tu kathoraprāyam evam aparah saṃdarbho mukhād ārabhya mṛdur antare kaținatarah sahakārapāka ity ucyate | (...) te 'mī traya eva śuddhapākāh | vyatikarajanmānas tu bhūyāmsaḥ | eta evārthapākāḥ pañcame prakārāntareṇa pratipādayiṣyante || Sarasvatīkaṇthābharaṇa commentary to 1.77 .

'Perfection' is accomplished at the beginning and at the end and it is divided into three types: coconut, mango, and grape. As the ripe fruit of coconut is hard in its skin, in its chief part there is a soft covering layer, and [then] it is much harder in its shell, in the same way some composition is harsh at the beginning, immediately after [that] rich in softness, but then harder again. ${ }^{10}$ This is the ripeness of the coconut. Thus, in the first $p \bar{a} d a$ of the mentioned example, the beginning four syllables in abhyuddhrta are hard, six syllables in vasumatī dali are soft, four syllables in tam ripūrah are harder because of anusvāra, letters $r$, and a long vowel. And here, according to our authorities, tam by arrangement rich in mildness, strengthens the conformity of the soft, shell and the upper side parts [of the expression]. Thus, in the three $p \bar{a} d a$ s beginning with the second, the resemblance to a coconut fruit should be ascertained by [the sequence of] four, six, and four syllables. Therefore, in the sentence starting with 'here' he [Bhoja] said how this kind of pāka arises. "Resulting from practice" (äbhyāsika), that is accomplished through exercise. Exercise is a repetitive practice in constructing and composing under the supervision of those who are skilled in writing and evaluating poetry. He said how that kind of pāka forms - "through the beauty of the composition" (...) Even if there is another word, it does not exist for the connoisseurs -

10 Coconut as a fruit also has three pericarp layers: exocarp (outer layer), mesocarp (fibrous husk) and endocarp (hard shell). Bhoja referred only to them, leaving out what is inside the coconut fruit: seed, coconut water and endosperm (white flesh). 
this is the common practice. This is the peculiarity of accomplished composition. How could it be otherwise? If its synonyms were put somewhere else in the composition, it would not be that pleasant. Therefore, this is vākyaguna - a quality of expression. And hardness occurs because of the consonant clusters or long vowels. Like here, in the example "ripurra", etc. Someone said that the ripeness of eggplant is characterized by proficiency in declination and conjugation, but this is the guna known as suśabdata - the felicity of speech. Starting from 'evam': As the softness of the grape starts with the skin, and inside it has a little hardness as it is filled with two, three or four seeds, in the same way, some compositions at the beginning and the end are soft and in the middle are hard. Ripeness endowed with slightly hard nature due to consonant clusters and long vowels is called the ripeness of the grape. $(\ldots)^{11}$ Therefore, as the author of Kavikalpalatā and some others stated, there is no fourth $p \bar{a} k a$ of blue wood apple. And as the ripe fruit of mango is soft at the beginning, but is hard in the kernel, another kind of composition, starting at the beginning as sweet, but harder in the middle, is called mature as mango. $(\ldots)^{12}$ These three are indeed pure pākas. There are more [types] born from mixing them. Those are indeed arthapākas and will be explained in the fifth chapter in another way.

It may be observed that Bhoja designates his classification of praudhi differently than Rājaśekhara. The latter describes ripeness of coconut as "sweet at the beginning and at the end" (ädyantayoh svādu nālikerapākam), the ripeness of grape as "not sweet at the beginning, but sweet at the end" ( $\bar{a} d \bar{a} v$ asvādu parin̄āme svādu mrivīkāpākam), and the ripeness of mango as "mediocre at the beginning and sweet at the end" (ādau madhyamam ante svādu sahakārapākam). Therefore, for Rājaśekhara, $p \bar{a} k a$ is connected with the taste, whereas Bhoja takes into account the anatomy of the fruit, distinguishing its soft and hard

11 I omit the example of stanza 5.34 from Kumārasambhava and the stanza of an anonymous author which comes with no further explanation.

12 I omit the example of the stanza of an anonymous author. 
parts. He sees the ripeness of coconut ${ }^{13}$ (nālikerapāka) as semi-hard at the fleshy part, soft inside and hard when one considers the shell, the ripeness of grape (mrdvīkāpāka) as soft but with some hardness inside and the ripeness of mango (sahakārapāka) as soft at the beginning and hard at the end. Therefore, he compares the texture of the particular layers of the above mentioned fruits to the phonetic attributes of the respective parts of the poem. According to him, the hardness of speech is caused by an accumulation of long vowels, anusvāras, consonants, the semivowel $r$, and consonant clusters. It is the right distribution of this hardness in the literary work and an accurate balance of sounds, that makes a poem perfect. It cannot be too harsh, but it cannot be too soft either-some hardness is desirable for literary composition. Hence, Bhoja is the first theorist to emphasise the sound effects of a literary work in the context of the theory of $p \bar{a} k a$ and explains all the features clearly. Now it is also obvious why according to him it is impossible to substitute words with their synonyms in a mature poem - this would affect the perfect balance of sounds.

Bhoja's predecessors related the theory of kāvyapāka to the allocation of taste in different fruits - therefore, the association was quite close to the rasa theory. Bhoja, on the other hand, examined the inside of the fruit; he divided the fruit into different layers and compared those to poetry. It is worth noting that his observations on the structure of fruits were botanically accurate. While explaining each type of $p \bar{a} k a$, he referred to the three actual pericarp layers of the fruit's anatomy. Therefore, in his approach, the relation between botany and poetics is more strongly outlined then in the views of the preceding theoreticians. It is also interesting to note that all image examples used by the theoreticians are, from the botanical point of view, fruits although their names may suggest differently (i.e. coconut, betel nut, cucumber, aubergine).

13 The $15^{\text {th }}$-century Sanskrit and Telugu poet, Śrīnātha, also compared the style of Sanskrit poetry to a ripe coconut. He pointed out that because of hard shell it is difficult to reach the sweet part of coconut - similarly, Sanskrit poetry, because of its elaboration also requires an effort from its reader (Narayana Rao: 1995). 
All fruits used by the theoreticians to describe different kinds of $p \bar{a} k a$ are indigenous to the Indian Subcontinent. Probably the authors intentionally chose the most easily accessible and widely known fruits. The most popular in India are fruits mentioned by Vāmana: mango, eggplant and wood apple. On that account, theoreticians could be sure that descriptions were clear and their symbolic meaning easily comprehensible to the readers. And were it not the case, aspiring poets could easily procure those fruits and use them as empirical tools to fully understand each type of $p \bar{a} k a$.

Bhoja and Ratneśvara agree with Rājaśekhara also on another matter. They believe that the ability to write perfect poems depends on extensive writing exercises. The commentator explains how young poets should train themselves in poetry. For him, the most important factors seem to be the frequency of undertaking the exercise and the supervision of a skilled teacher. Rājaśekhara says nothing about how young poets should develop their skills in attaining the perfection; however, at the end of his classification of pa kas he mentions that he prepared the whole expose specifically for those who train in writing poetry. Perhaps he wants them to be able to determine by themselves the ripeness of their works.

Another disagreement with former theoreticians discussing $p \bar{a} k a$ may be seen in the description of the ripeness of eggplant provided by Ratneśvara in the commentary. It stands in opposition to the statement of Vāmana who says that this kind of ripeness is based on grammatical sophistication and touches a difficult matter; also, it is a peculiarity of bad poetry. Bhoja and his commentator see the linguistic perfection as a merit. For them, it is a guna of the felicity of expression-suśabdatā. Neither the theoretician nor the commentator explain what does the ripeness of eggplant mean in their opinion. It may be observed that Bhoja and Ratneśvara also oppose Mangala as they do not consider grammatical correctness as praudhi.

Bhoja writes about praudhi also in the first pariccheda of Sarasvatikanthäbharana. He lists it among arthagunas, providing this definition: "Praudhi is known as the result of expressing the intended meaning 
in poetry" (vivakșitārthanirvāhah kāvye praudhir iti smṛtā $\|$ Sarasvatīkanthāäbharana 1.88). Further, Bhoja explains: "Thus praudhi is the completion of intended meaning because of procurement of mature meaning by separate sentence" (etāvatah prabhütasyārthasyānekavākyena pratipāditatvād vivakșitārthanirvahanam prauḍhi \| Sarasvatīkanthābharana 1.88). Ratneśvara adds: "When great meaning desired by the poet is bestowed on even a short sentence this is praudhi" (kaver abhimatasya bhüyaso "py arthasya svalpenaiva vākyena pratipādanam praudhih || Sarasvatīkanțähharana, commentary to 1.88). Therefore, according to Bhoja, praudhi-in the categories of arthaguna - is the ability of the poet to successfully communicate through a poem the meaning which he constructed in his mind and deliver this meaning in a compendious way. This can be defined as poet's power to accomplish his intention. According to Bhoja, literature which is mature from the point of view of artha is concise but meaningful. A mature poem should not be more elaborate than needed to express everything that was undertaken by the poet. In the definition of praudhi as an arthaguna provided by Bhoja, similarities to the views of Vāmana regarding praudhi in the explanation of another arthaguna - ojas - may be observed. Both theorists consider it the foremost ability of a writer to attain the intended result while imparting momentous sense in a brief speech. Although his definition is in fact devoted to ojas, Vāmana specifies also five types of praudhi, which the fact is not taken into consideration by Bhoja.

Pāka is mentioned by Bhoja in the Sarasvatikanthäbharana one more time. In the fifth pariccheda, Bhoja speaks of three päkabhaktis. In verse 5.124 he once again mentions the three kinds of $p \bar{a} k a$, already which he discussed in the first pariccheda: ripeness of coconut, mango, and grape. The next verse classifies them as premabhaktisvarieties of love. The author places them amongst the features of rasa. There are no further explanations provided by Bhoja, and this part of Sarasvatīkanthābharana also lacks commentary.

Bhoja mentions pāka in his other treatise on poetics, Śrngāraprakāsa, as well. In the last and thirty-sixth chapter of this work, 
he provides a list of twelve premapākas_-varieties of preman, a new rasa introduced by Bhoja. However, this chapter has not been preserved as a whole and therefore more than half of the list is lost. The types of premapāka that have come to us are as follows: picumandaneem, kapittha-wood apple, kramuka-betel nut, kharjūra-date. V. Raghavan suggests that the next three are kinds of $p \bar{a} k a$ mentioned in the Sarasvatīkanthābharana in verse 5.124 (Raghavan 1978: 66). The other five are unknown. It is interesting that kapittha pāka is mentioned here, because in the commentary to the Sarasvatīkanthābharana 1.77 Ratneśvara maintains that in poetics there is no such thing as nilakapittha pāka - "the ripeness of blue wood apples".

There is no doubt that the contribution of Bhoja to the theory of $k \bar{a} v y a p \bar{a} k a$ was truly significant. Although he was aware of the views of his predecessors, he managed to see the concept in a different light and provide original perspective to the discussion on the perfection of poetry.

\section{References}

\section{Primary sources}

Kāvyālan்kāra= P. V. Naganatha Shastry (ed. and trans1.). 1970. Kāvyālañkāra of Bhāmaha. Delhi-Varanasi-Patna: Motilal Banarsidass.

Kāvyālamkāarasūtravrtti = M. Durgāprasāda, K.P. Parab (eds). 1926. The Kāvyālankāra Sütras of Vāmana, with His Own Vṛtti. Bombay: Nirnaya Sagar Press.

Kāvyamìmāms ā = C. D. Dalal, R. Anantkrishna Shastry (eds). 1934. Kāvyamìmāmsā of Rājaśekhara. Baroda: Oriental Institute.

Sarasvatīkaṇthābharaṇa = K. Śarmā, W. L. Sāstrī Paṇśīkar (eds). 1934. The Sarasvatī Kanțābharana by Dhāreśvara Bhojadeva, with Commentaries of Rämsimha (I-III) and Jagaddhara (IV). Bombay: Nirnaya Sagar Press. 
Śrñgāraprakāśa = G. R. Josyer (ed.). 1955-1958. Maharaja Bhojaraja’s Sringara Prakasha vol. I-IV. Madras: Coronation Press.

\section{Secondary sources}

Battistini, A. 2016. When Poetry Is Ripe: An Overview of the Theory of kāvyapāka. In: C. Pieruccini and P. M. Rossi (eds). A World of Nourishment. Reflections on Food in Indian Culture. Milano: Ledizioni: 145-161. https://doi.org/10.13130/2611-8785/310717.

Cox, W. 2012. Bhoja's Alternate Universe. In: Journal of the Royal Asiatic Society, 22 (1): 57-72. https://doi.org/10.1017/S1356186311000770.

Kane, P. V. 1961. History of Sanskrit Poetics. Delhi-Varanasi-Patna: Motilal Banarsidass.

Krishnamachiariar, M. 1974. History of Classical Sanskrit Literature. DelhiVaranasi-Patna-Bangalore: Motilal Banarsidas.

Krishnamoorthy, K. 1971. Mangala, a Neglected Name in Sanskrit Poetics. In: Journal of the Oriental Institute of Baroda, 20 (3): 247-55.

Lipowska, L. 2016. Śajja i paka. In: S. Cieślikowski, Teoria literatury w dawnych Indiach. Kraków: Księgarnia Akademicka: 351-355.

Narayana Rao, V. 1995. Coconut and Honey. Sanskrit and Telugu in Medieval Andhra. In: Social Scientist, 23: 24-40. https://doi.org/10.2307/3517881.

Raghavan, V. 1973. Studies on Some Concepts of the alamkāra śāstra. Madras: The Adyar Library and Research Center.

Raghavan, V. 1978. Bhoja ’s Śrngāra Prakāśa. Madras: Vasanta Press.

Sircar, D. 1953. Mahākavichakravartin Chhittapa. In: Proceedings of the Indian History Congress, 16: 124-128. 